\title{
Educação popular e trabalhos autogestionários: iniciativas operando (re)arranjos em territórios vulneráveis
}

Popular education and self-managed work

Community Health: initiatives operating (re)arrangements in vulnerable territories

Educación popular y trabajos autogestionados: iniciativas operando (re)arreglos en territorios vulnerables

LINDOMAR WESSLER BONETI (iD ${ }^{a}$ MARia José Menezes Lourega BeLLi (D)

Resumo

O presente artigo tem como objetivo analisar a educação popular como prática geradora de laços de convivência que potencializem ações comunitárias, transformando condições de vulnerabilidade em espaços ambientalmente sustentáveis. Metodologicamente, esse movimento de aprendizagem compartilhada, geradora de realizações, será analisado por meio da reconstituição

\footnotetext{
a Pontifícia Universidade Católica do Paraná (PUCPR), Curitiba, Paraná, Brasil. Doutor em Sociologia, e-mail: boneti.lindomar@pucpr.br

${ }^{\text {b }}$ Pontifícia Universidade Católica do Paraná (PUCPR); Universidade Tecnológica Federal do Paraná (UTFPR), Curitiba, Paraná, Brasil. Mestre em História, e-mail: mariajosebelli@uol.com.br
} 
do itinerário da Irmã Tereza Araújo e do CEFURIA. A abordagem se propõe desvelar e analisar os reposicionamentos desses atores em ambientes de aprendizagem geradores de problematizações sobre suas condições sociais em meio a mercados modelados por trocas emocionais, simbólicas, produtivas e financeiras. Compreender as posições e posicionamentos desses grupos com seus interlocutores possibilitou identificar suas parcerias junto a esferas institucionais, bem como analisar os (re)arranjos solidários como práticas pedagógicas, onde esquemas mentais foram formados através de repertórios provenientes de vivências, capazes de agregar transformações em microterritórios urbanos. Desses encontros surgiram comunidades de aprendizagem, visões diferentes chegaram a consensos, dos esforços individuais ocorreram convergências pela cooperação. Quando se instalou essa rede de interdependência, as contradições emergiram, eram proferidas em rodas de conversa, assim o senso crítico ganhava terreno ampliando as margens de luta por uma cidade mais inclusiva e democrática. No que se refere aos caminhos teóricos, adotaram-se no estudo Freire e Freire (2014), Polanyi (2000), Porto-Gonçalves (2006), Sen (2010) e Gadoti (1991). Assim, a Associação de Moradores Santo Inácio de Loyola e o CEFURIA possibilitaram examinar um conjunto de situações e sistemas de pensamento que substituíram resignação pela opção de reorganizar suas vidas.

Palavras-chave: Educação popular. (Re)arranjo solidário. Autogestão. Pedagogia.

\section{Abstract}

This article aims to understand, from the trajectory of the popular educator Sister Araújo and CEFURIA - Sister Araújo Rural Urban Training Center, how workers living in conditions of vulnerability in Curitiba managed to overcome the formalism of social relations through supportive practices. The approach proposes to unveil and analyze the repositioning of these actors in a fractioned and differentiated urban space, as much by the economic relations as by the interventions of the managers of the public administration. Evidencing and understanding the positions and positioning of these groups of residents and their main interlocutors also led us to explore ways of movement capable of detecting through listening of what was agreed upon, the definitions that underwent redefinitions, requiring these subjects to be willing to continue to that had been arranged, that is, the (re)arrangement became a constant, and demanded the strengthening of solidarity. In this sense, the proposal is also concerned with the commitment of demonstrating the ability of collective management to create solutions to common problems. With this perspective, it aims to decode how the economic needs of micro-collective spaces made it possible to think of the economy as markets shaped by emotional, productive and financial exchanges. The theoretical paths were developed by Freire and Freire (2014), Polanyi (2000), Porto-Gonçalves (2006), Sen (2010) e Gadoti (1991).Thus, the Association of residents of St. Ignatius of Loyola and CEFURIA made it possible to examine a set of situations and systems of 
thought that, when living with pre-established social configurations, decided to substitute resignation for the option of reorganizing their lives.

Keywords: Popular education. (Re)solidarity arrangement. Self-management. Pedagogy.

\section{Resumen}

El presente artículo tiene como objetivo analizar la educación popular como práctica generadora de lazos de convivencia que potencialicen acciones comunitarias, transformando condiciones de vulnerabilidad en espacios ambientalmente sostenibles. Metodológicamente, ese movimiento de aprendizaje compartido, generador de realizaciones, será analizado por medio de la reconstitución del itinerario de la Hermana Tereza Araújo y del CEFURIA. El abordaje se propone desvelar y analizar los reposicionamientos de esos actores en ambientes de aprendizaje generadores de problematizaciones sobre sus condiciones sociales en medio a mercados modelados por intercambios emocionales, simbólicos, productivos y financieros. Comprender las posiciones y posturas de esos grupos con sus interlocutores posibilitó identificar sus asociaciones junto a esferas institucionales, así como analizar los (re)arreglos solidarios como prácticas pedagógicas, en los que esquemas mentales fueron formados a través de repertorios provenientes de vivencias, capaces de agregar transformaciones en micro territorios urbanos. De esos encuentros surgieron comunidades de aprendizaje, visiones diferentes llegaron a consensos, de los esfuerzos individuales ocurrieron convergencias por la cooperación. Cuando se instaló esa red de interdependencia, las contradicciones emergieron, eran pronunciadas en rondas de conversación, así el sentido crítico ganaba terreno ampliando los márgenes de lucha por una ciudad más inclusiva y democrática. En lo que se refiere a los caminos teóricos, se adoptaron en el estudio Freire y Freire (2014), Polanyi (2000), Porto-Gonçalves (2006), Sen (2010) y Gadoti (1991). Así, la Asociación de Vecinos San Ignacio de Loyola y el CEFURIA hizo posible examinar un conjunto de situaciones y sistemas de pensamiento que sustituyeron resignación por la opción de reorganizar sus vidas.

Palabras-clave: Educación popular. (Re)arreglo solidario. Autogestión. Pedagogía.

\section{Introdução}

O presente artigo tem como proposta buscar compreender a educação popular como prática geradora de laços de convivência que potencializem ações comunitárias, transformando condições de vulnerabilidade em espaços ambientalmente sustentáveis. Esse movimento de aprendizagem compartilhada, gerador de realizações, será analisado por meio da reconstituição do itinerário da 
Irmã Tereza Araújo, pela Associação de Moradores Santo Inácio e pelo Centro de Formação Urbano Rural Irmã Araújo (CEFURIA). O interesse por essas experiências adquire sentido nesse estudo por ser um caminho, dentre muitos, para se compreender como o fortalecimento de ambientes de aprendizagem pautados pela reciprocidade instalam contrapontos ao mercado concorrencial. Isso nos induz a pensar sobre a capacidade dos (re)arranjos solidários de consolidarem escalas valorativas baseadas na autogestão, cooperação, coobrigações para coconstruírem empreendimentos fortalecedores de tecnologias sociais, demarcação de lugares no âmbito escolar e político, bem como na defesa de uma cidade democrática. Observa-se aí a generosa dinâmica das brincadeiras de roda que, ritmada pelos participantes, se forma, se abre, muda seu desenho e tamanho, mas continua defendendo o seu lugar de fala e de influência em redes de interações.

\section{(Re)arranjos solidários: a liberdade sendo impulsionada pelos sentimentos morais}

Evidenciamos como questão inicial a importância de compreender o mercado integrando várias formatações de troca, para assim poder observar que, na especificidade dessas inter-relações, o emprego dos sentimentos morais pode oscilar em graus e conteúdo. Os referenciais de valor, quando apenas consideram o material e desprezam os valores morais, acabam por transformar as equações numéricas em uma disputa de ambições irrefreáveis. O labirinto de confusões se instala e com ele bandeiras são erguidas na defesa do poder econômico e não da necessária retomada dos sentimentos morais. Daí, na proteção da integridade da vida humana e da sustentabilidade ambiental, muitos movimentos emergem, se pulverizam em muitas causas e, com elas, as pautas políticas passam a ser pensadas nos territórios carentes de sentimentos morais. Os desafios que se apresentam são muitos:

por esse motivo a democracia pluralista exige não apenas consenso em um conjunto de princípios políticos comuns, mas também a presença de dissensão e instituições por meio das quais tais divisões podem ser manifestadas. É por isso que sua sobrevivência depende de entidades coletivas formando-se em torno de posições claramente diferenciadas, bem como, sobre a possibilidade de escolher entre alternativas reais (MOUFFE, 2001, p. 419). 
É também igualmente importante incluir nessa reflexão especificidades dentre as plurais manifestações políticas, e assim, demarcar que os movimentos somente serão efetivamente alternativos se forem capazes de se reinventarem por meio da geração de articulações que tenham em sua essência a reciprocidade. A substancialização desses movimentos reatualizam as relações no mercado, retomam referenciais estruturais de convivência para anunciar que "uma parte considerável de nossa moral e de nossa própria vida permanece estacionada na mesma atmosfera em que dádiva, obrigação e liberdade se misturam” (MAUSS, 2017, p. 308).

Essa mensagem deixa claro que o intercâmbio material integra-se ao imaterial, estabelecendo uma riqueza de cadeias associativas com esferas dialógicas, e que, embora as experiências alternativas não estejam imunes a zonas de turbulências, os pontos de pactuação contribuem para a defesa dos valores associativos diante de vicissitudes.

A "dádiva" não é uma fórmula a ser replicada, um manual de segurança para blindar contra as crises, um mapa com roteiros de como chegar. Muito diferente disso, Adam Smith compreendeu que é uma difícil construção sujeita a desconstruções, pelo "toma lá, dá cá" do mercado. Mas, mesmo assim, insiste em situar os sentimentos morais que mediavam os mercados comunitários como um farol capaz de:

orientar todas as nossas ações para promover o maior bem possível, em submeter os afetos inferiores ao desejo de felicidade geral da humanidade, em considerar-se apenas como um dentre muitos, cuja a prosperidade não deveria buscar além do que fosse consistente com a felicidade do todo ou além do que conduzisse a esta, consistiria a perfeição da virtude (SMITH, 1999, p. 376).

Deste modo, pode-se entender que o sistema de valores que conjuga princípios morais com procedimentos fraternos seria referencial disciplinador das ambições utilitaristas. Esse sistema de virtudes correspondidas, nutridas pela empatia, denuncia que o individualismo, ao ser guiado pelo desmedido ganho financeiro, desenvolve escalas de incertezas, provocando profundas adversidades sociais. Então, a imposição dos vínculos de dependência hierarquizadores, sobrepondo-se aos de cooperação, pode até representar a vitória do poder econômico, mas não expressa um caminho para a sustentabilidade ambiental e, por extensão paradoxal, mostra-se fundido nesse mecanismo de perturbadoras situações de instabilidade. Pensando nisso: 
a contribuição do mecanismo de mercado para o crescimento econômico é obviamente importante, mas vem depois do reconhecimento da importância direta da liberdade de troca - de palavras, bens, presentes, diferentes formas de liberdade (SEN, 2010, p. 20).

Nesse cenário, marcado por atores com posições divergentes e com embate de forças desiguais, destacam-se o enlace de dois processos que corroem a vida comunitária. O primeiro se refere à fragilização da memória coletiva e o segundo, ao desmonte da função social do trabalho. Esse jogo de pressão e resistência aparece na obra Pierre Bourdieu. En Argelia. Imágenes del desarraigo. As observações e fotografias resgatam a memória coletiva daquele território, impactado pelo conflito com a França. São imagens que se compõem de percepções e parte dessa tensão é evidenciada por:

Los hombres dicen ahora "cada uno por su panza", "cada uno mira para si mismo", cuando antes se decía "cada uno su tumba", porque sollo allá abajo (en el más allá) cada uno se confrontará com sus actos: ese dia no puedo hacer nada por ti, ni tu puede hacer nada por mi, mientras que aqui la vida no es posible sin la ayuda mutua (SCHULTHEIS; FRISINGHELLI, 2011, p. 134).

Essa narrativa revela um embate, uma fratura das tradições comunitárias desorganizando uma rede de convivências com uma dada memória coletiva. São interdependências fortalecidas pelas trocas emocionais e materiais. Esse sistema de microlealdades entende que:

El trabajo no es ni un fin ni una virtud por sí mismo. Lo que se valora no es la actuación orientada hacia un fin económico sino la propia actividad, independientemente de su función económica y con la única condición de que tenga una función social (SCHULTHEIS; FRISINGHELLI, 2011, p. 154).

Evidencia-se que os muitos e variados afazeres exteriorizam criatividade, necessidades, emoções, crenças, como também aprendizagens, que dão nexo a existência do grupo, pois desencadeiam esquemas mentais que fornecem sentido, significado a essas realizações. É um esforço plural com reconhecimento de todos.

Esse entendimento manifesta a importância da solicitude de um para com o outro como um contínuo guia, ou seja, as relações de reciprocidade criam condições para novas aprendizagens, feitas com senso crítico e pela necessidade de sobreviverem. Percebem que a força do individualismo, do "cada uno por su panza" está indissociado do esgarçamento do tecido social que vivem e agora precisam 
refazer suas vidas. Assim, esses pontos de intersecção abrem janelas para nos mostrar que, no intercâmbio de saberes e experiências, nos "cabos de guerra" cruzados e tensionados, o individualismo, mesmo vitorioso, não aniquila ou domestica o senso de honra compartilhado na vida comunitária.

O agir em comum ao criar acordos e transformá-los em ação busca assegurar espaço por meio das relações horizontais de reciprocidade. Para isso necessita imprimir reordenações que resultem em mutações na defesa da permanência. Neste sentido, a gestão dos problemas define uma dinâmica no coletivo, exige a construção da autogestão pela aprendizagem constante, pois, segundo Porto-Gonçalves (2006, p. 51), "mais que resistência, o que se tem é R-Existência posto que não se reage simplesmente a ação alheia, mas sim que algo pré-existe e é a partir dessa existência que se R-existe. Existo, logo resisto”.

Assim, por meio desse caminho, pode-se ir além e entender que se encontra internalizado no (re)arranjo solidário a ousadia em "R-existir". Na essência, esses processos relacionais adquirem feições dadas pelas experiências vivenciadas, pois resultam das relações pessoais e contingências sociais deixando marcas na trajetória de vida dos sujeitos. Sua plasticidade move-se nesse inacabado fazer-se e torna perceptíveis as microiniciativas impregnadas de incertezas e experimentações solidárias, tendo que continuamente se recompor para não perder de vista o senso de coconstrução coletiva. É a existência que "R-existe".

Deste modo, os (re)arranjos solidários são dinâmicas de aprendizagens críticas e criativas voltadas a gerarem permanentes rearrumações. Dito de outra forma, essas condições comprometem as:

atividades de trabalho, produção e troca para rearranjar a sociedade de acordo com um direito novo, oriundo das práticas e das relações concretas entre os indivíduos e as funções. Da mesma forma como os ideais nascem das forças coletivas, um direito novo se desenvolve para regrar as relações entre os indivíduos (DARDOT; LAVAL, 2017, p. 396-397).

O ambiente em reestruturação se faz por pactos de convivência movidos pela reciprocidade e pela ação coletiva capaz de criar oportunidades de autotransformação dos sujeitos na medida em que fornece respostas coordenadas diante de complexas necessidades diárias. 
O trabalho de aprimorar os processos decisórios pelo debate abre espaço para concomitantemente revisar tais procedimentos de modo a manter a coerência autogestionária, bem como, assegurar o compartilhamento do que foi gerado. A insistência em aprender por meio do respeito aos dissensos e o fortalecimento dos consensos atualiza os combinados e demarca diferenciações, bem como elabora críticas às relações sociais que reproduzem a subalternização em ambientes estruturalmente vulneráveis. Esses coletivos, por tais caminhos de reflexão, produzem descobertas, interiorizam e reelaboram conhecimentos, externalizam concepções de mundo produzidas na realidade empírica. Todos esses fios argumentativos são tramados na prática da educação popular que é:

una propuesta educativa con un acumulado propio, que la saca de la acción intencionada en grupos sociales populares para convertirla en una actuación intencionadamente política en la sociedad para transformar y proponer alternativas educativas y sociales desde los intereses de los grupos populares, evitando caer en el utopismo educativo y pedagógico que cree que solo cambiando su educación se transforma la sociedad y hace conciencia de que si no cambia la educación, será imposible transformar la sociedad (MEJíA J., 2013, p. 369).

A organização dessa rede de repertórios através das práticas desenvolvidas pela educação popular autotransforma as pessoas, desenvolve pontos de convergência alargando o sentimento de reciprocidade. Assim, cria um campo político pedagógico capaz de se fazer reconhecer como ativo participante nos espaços geradores de conhecimento, bem como busca materializar lugares mais justos em que se viver. Intrínseco a esses espaços educativos de convivência, encontra-se a micropolítica, uma complementaridade que, coconstruída, transforma mapas mentais e físicos.

Todo esse esforço pode ter um caráter transitório de alívio diante das adversidades ou pode adquirir potencialidade a ponto de transformar reivindicações em direito. Assim, é importante olhar para dentro das lutas sociais, identificar seus atores, suas especificidades, sem perder a percepção das suas inter-relações externas, pois suas conquistas, segundo Polanyi (2000, p. 185), “dependerão da sua habilidade em ganhar apoio fora da sua própria coletividade, e isso também dependerá da possibilidade de executarem as tarefas estabelecidas por interesses mais amplos do que o seu próprio".

A arena política amplia-se além das obrigações eleitorais e das disputas partidárias. Juntam-se nesse campo parlamentar manifestações populares, que, por 
meio de mobilizações, pressionam os gestores públicos. São ações por vezes espontâneas e por vezes orquestradas que acabam por interferir na forma como a cidade é administrada. Identificam-se na interação dessas várias lógicas de participação democráticas as ligações comunitárias estabelecidas pela Associação de Moradores Santo Inácio de Loyola e o CEFURIA como “alternativas reais" para "O exercício de reciprocidades concretas". Por isso, recolocam-se os (re)arranjos solidários como dinâmica e como oportunidade para examinar processos decisórios voltados a territorializar com autogerenciamento e sustentabilidade. Agregam-se aqui novas reflexões e entendimentos, pois a ampliação do foco sobre as convivências comunitárias permite identificar o endereço, desvelar experiências e interpretar falas. Assim, a ideia é contextualizar o vivido, registrar no mapa da memória afetiva da cidade espaços constituídos pelos sentimentos morais, para assim viabilizar a sua localização.

\section{Histórias contadas, propósitos desvelados}

Maria Pinheiro Araújo, cearense de Pacotí, nasceu em 1919 em um contexto rural. Quando completou 18 anos foi para o Rio de Janeiro e ingressou na Companhia da Caridade de São Vicente de Paulo, onde desenvolveu sua formação e cursou enfermagem.

Os trajetos percorridos pela Irmã Araújo ganharam novos elementos na década de 1960, quando se aproximou do Instituto Superior de Pastoral Catequética (ISPACRJ). Sua presença neste contexto, marcado pelo Concílio Vaticano II, lhe permitiu disseminar a mensagem do papa João XXIII, que buscava, em sua essência, afirmar: "a Igreja é de todos, mas principalmente quer ser uma Igreja dos pobres". Com essa fala materializaram-se novas experiências religiosas e, no caso da América Latina, provocou-se um redimensionamento a partir das Conferências de Medellín (1968) e Puebla (1972). Nascia nesses encontros uma geração com ideias que inspiraram a formação da Teologia da Libertação, das Comunidades Eclesiais de Base e as Pastorais.

Todo esse contexto se entrelaçava com as opções da religiosa Irmã Araújo, que participava ativamente como educadora popular e na defesa da democracia. Por 
isso, de imediato atendeu o chamamento da Pastoral do Enfermo, da Pastoral Popular e da Pastoral Carcerária, em Curitiba. Em 1969, se integrou ao grupo de enfermeiras do Hospital de Clínicas. Paralelamente a essa atividade, se aproximou da Associação Difusora de Treinamento (ADITEPP), objetivando identificar os bairros onde os moradores enfrentavam condições de adversidades estruturais e que necessitavam de ações transformadoras para minimizar seu sofrimento. As Irmãs Lindinha e Adiles juntaram-se à Irmã Araújo. O desafio foi grande: percorreram várias regiões e conversaram com muitas pessoas, de tal modo que, ao decidirem ir para o Boqueirão para formar o centro comunitário, já haviam estabelecido laços de amizade com grande parte dos moradores.

Após terem alugado uma casa, resolveram tornar esse espaço um referencial de integração e mobilização. Assim, em 1973 a Associação Comunitária Santo Inácio de Loyola foi registrada em cartório. Um marco histórico: surgia, no bairro do Boqueirão, a primeira Associação de Moradores com reconhecimento legal na cidade de Curitiba.

Portanto, toda essa organização foi tecida pela lente do sonho possível que:

já de pronto para sobreviver, nasce brigando. Esse parto contraria certa tradição que tem sido hegemônica em nossa cultura. Emergindo tal como faz, esse projeto parteja uma proposta que rearranja nossa tradição acadêmica e científica (FREIRE; FREIRE, 2014, p. 234).

Aparece aqui, por meio das reflexões de Freire, a pedagogia dialética do conflito como um caminho para interpretar a tensa hierarquização valorativa entre os campos do conhecimento e por extensão sua operacionalização em empreendimentos econômicos esvaziados das disposições marcadas pelos sentimentos da dádiva. Então é importante reconhecer, nas contínuas situações de aprendizagens solidárias, contribuições capazes de decifrar as vigas sustentadoras da epistemologia moderna e visualizar no pensamento educacional a presença de uma concepção etnocêntrica capaz de afirmar vigorosamente que:

existe uma verdade única e universal, entendida como centro, e é a partir dela que se institui os parâmetros de verdade, do que se considera certo e errado. $\mathrm{O}$ etnocentrismo tem origem justamente da razão científica, do entendimento que a ciência é única e universal, que a verdade científica guarda requisitos universais que a distingue como ciência (BONETI, 2009, p. 166). 
Com esse entendimento os profissionais portadores do conhecimento culto potencializam a instrução em um circuito produtivo. A excelência reconhecida pelos seus pares formaliza sistemas de pesquisa e ensino com bases curriculares pautadas em desenvolver talentos para triunfar, em ambientes sociais geradores de oportunidades desiguais. Outra face dessa mesma tensão permanente são as atitudes de um pensar e fazer pedagógico que, por não estarem engessadas na escolarização pautada por habilidades e competências, na educação continuada e submetida a escalas avaliativas seletivas, pode interrogar tais dinâmicas, provocar e insurgir com a possibilidade de gerar itinerários propostos e desenvolvidos no diálogo horizontal e coletivo.

O que inquieta é que todo esse fazer pedagógico pode conquistar vários espaços, estando em frentes de organização popular, contribuindo para alargar a organização curricular, em promover redimensionamentos na comunidade escolar além do seu espaço físico. Possibilita, sobretudo, entrecruzar na formação de educadores uma forma de pensar e agir capaz de inserir a quebra da racionalidade moderna. Incrusta uma posição de insurgência contra um processo de ensino que trata o desigual como aquele que carrega fracassos em uma escala de níveis de diferenciação; se nega a adotar sistemas de triagem voltados a gerar extensos registros estatísticos que classificam como minoria todos que demonstram incapacidade em adquirir reconhecimento social.

Mas é importante dizer mais e reconhecer que mesmo que essa abordagem já tenha sido desenvolvida é imprescindível revitalizá-la, pois seu silenciamento possui impactos devastadores no processo de humanização. Continuando, se existe qualidade em exercitar a pedagogia do conflito também existe originalidade, esperança e força na educação comunitária mobilizada pela Irmã Araújo, já que ela contribuiu para tornar a Associação dos Moradores um ambiente de aprendizagem e tomou para si a convicção de que:

a tarefa do educador, nesta sociedade, é a de criar condições objetivas que favoreçam um novo tipo de pessoa: solidárias, organizadas, capazes de superar o individualismo da educação capitalista (GADOTI, 1991, p. 121).

Gerar todas essas experiências parece inicialmente inviável, mas ousadias existem e tais motivações vão além do arrojo inicial, possuem fundamentação 
teórica, adotam procedimentos investigativos e análises rigorosas. São educadores que pela sua formação percebem a educação através da cooperação, autogestão e sustentabilidade; deste modo, a coerência está em afirmar o ser autônomo, plural, dialógico com liberdade de pensamento e criação.

Compreendendo toda essa complexidade, Freire adota o verbo partejar, porque se remete a fazer com alguém, uma integração geradora de concepções pedagógicas comprometidas em desenvolver através das contradições formas de conhecimento emancipadoras, experiências intensamente transformadoras, pois a reciprocidade se torna a essência da educação.

Com a disposição de partejar, a inserção da Irmã Araújo na comunidade não se deu por improviso e nem por práticas de caridade, ou seja, o enfrentamento das dificuldades se fez por meio de estudos preliminares seguidos pelas articulações e engajamento das religiosas conjuntamente com as famílias que ali moravam. Toda essa caminhada foi desencadeada por combinados geradores de transformações nas relações que uniam o grupo e nos espaços de convivência.

As descrições realizadas pela Irmã Araújo ao circular pela comunidade revelavam uma complexa adversidade. As andanças foram desenvolvendo coragem e isso lhe conferiu expressão na medida em que se tornou um movimento que:

afirma, lança suspeita, arrisca, transgride, respeita etc., as trajetórias que "fala". Todas as modalidades entram aí em jogo, mudando a cada passo, e repartidas em proporções, em sucessões, e com intensidades que variam conforme os momentos, os percursos, os caminhantes (CERTEAU, 1994, p. 179).

O fazer junto se dava de várias formas: eram organizados bailes comunitários para arrecadar recursos, mutirões na construção de casas ou valas para colocar manilhas, comissões e abaixo-assinados para pleitear obras públicas junto à prefeitura e empresas prestadoras de serviços de água, saneamento e de energia elétrica. Segundo Souza (2007, p. 71), ocorria também a formação de parcerias geradoras de recursos através da Secretaria de Indústria e Comércio do governo do Estado do Paraná e da CEBEMO/Vastenaktie, organização holandesa. Os trabalhos redefiniam continuamente as fronteiras do possível e organizaram-se cursos profissionalizantes, como eletricista, pedreiro, costura, bordado e enfermagem. 
As informações obtidas sobre as condições da comunidade identificaram vários problemas, como a falta de moradias dignas, transporte público, postos de saúde, energia elétrica, mas o emergencial era água encanada, abertura de valetas e aterro, afinal, a população vivia em um banhado insalubre. A pressão reivindicatória era contínua. Um exemplo foi a água encanada, pois a mobilização iniciada em 1973 apresentou algum resultado somente em 1976, com a instalação de uma torneira pública. A partir dá, o grande desafio foi construir uma rede de saneamento beneficiando todas as moradias e, para tal, foi criada uma fábrica de manilhas. Conjuntamente a esse empreendimento, organizaram um Posto de Saúde.

A presença da Irmã Araújo aglutinou um conjunto de interesses, sua rede de sociabilidade revelava suas frentes de atuação e nesse sentido também se fez presente na pastoral carcerária. Suas visitas à penitenciária do Ahú e penitenciária feminina de Piraquara eram semanais, em um momento em que o Brasil enfrentava uma ditadura militar. Toda essa multiplicidade de ações reveladas no relatório da Comissão da Verdade (COMISSÃO ESTADUAL DA VERDADE "TERESA URBAN", 2014) evidenciou a preocupação da Igreja em ocupar os mais variados espaços, e a presença da Irmã Araújo foi determinante nessa estratégia.

Deste modo, os vários traçados relacionais e dialógicos, construídos através da implantação em rede do projeto religioso, estabeleceram uma base de colaborações. Assim, foi possível observar nas rodas de conversa na comunidade Santo Inácio de Loyola a intersecção de outros canais de participação desejosos de amplificar a produção, circularidade e reinvenção de conhecimentos e saberes por meio da educação popular. Desses encontros definiu-se outro grupo e um novo espaço de atuação a ser explorado — surgia em 1981 o CEFURIA. A escolha do nome CEFURIA expressou justamente a ideia de ampliação do coletivo ao incluir o nome da religiosa em sua identidade - Centro de Formação Urbano Rural Irmã Araújo -, valorizando seu legado por suas práticas. Esse ambiente rico de intercâmbio de experiências serviu de estímulo para a criação da Escolinha de Formação Solidária - era um momento marcado pelo processo de redemocratização do país, onde as demandas sociais organizavam sua pauta política e econômica. Os obstáculos eram muitos e as soluções estavam sendo construídas. 
Nesses embates a Irmã Araújo já não mais estava presente, pois faleceu um pouco antes da formação do CEFURIA.

Neste mosaico, constituído por diferentes mãos, o sentimento de perseverança mantém todos juntos, convidando todos a participarem. Novas frentes de ação se materializaram por meio da Escolinha, que vem atuando junto aos catadores e catadoras de materiais recicláveis, nos clubes de troca, na feira de economia popular solidária, nas padarias comunitárias, junto à população em situação de rua, na segurança e soberania alimentar, bem como na reforma agrária e economia solidária. Dentre os diferentes contextos de aprendizagem, igualmente relevantes, centralizaremos nossa atenção nas experiências das padarias comunitárias, uma vez que o coletivo confeccionou um livro e um fanzine que mostram por meio de suas falas como decodificam suas realidades, problematizam sobre os desafios que cercam os caminhos viáveis e anunciam suas motivações. Assim, observa-se que a Escolinha intensifica trocas "culturais que foram operadas da escola em direção a outros setores da sociedade em termos de formas e conteúdos e, inversamente, as transferências culturais operadas a partir de outros setores em direção à escola" (JULIA, 2001, p. 37).

O livro Multiplicando as sementes foi elaborado no coletivo das padarias e narra o surgimento do primeiro empreendimento em 1996, destacando o papel de 20 mulheres que contaram com a parceria da Paróquia Nossa Senhora Auxiliadora, no Sítio Cercado em Curitiba. Com esses primeiros passos, a experiência gerou renda e contribuiu para a melhoria das condições de vida do grupo. Em 2005, por meio de recursos do Governo Federal, o CEFURIA ampliou para 30 a quantidade de padarias comunitárias, tornando o Paraná o Estado líder nessa área de empreendimento econômico solidário (CEFURIA, 2016, p. 7).

O livro narra a trajetória da organização das padarias, as reuniões com os grupos e o processo de composição e, nesse fazer, várias temáticas foram colocadas, imagens foram feitas e um álbum de recordações foi tecido pelas mãos das padeiras.

Dentre os muitos relatos, chama a atenção o de Jacinta Ramos de Paula, por mostrar como situações e limites enfrentados individualmente puderam ser alterados pela participação em rodas de conversas. Ela nos diz: 
eu faço pães, bolos, faço farofas e de tudo e mais um pouco, saio vender na rua, faço faxina na padaria. Pra mim, participar da padaria mudou muita coisa. Aprendi a trabalhar com os pães, vou nas reuniões, aprendi muito a me comunicar com o público, tenho muitas amizades, todo mundo me conhece na rua. Aonde estou eles gritam "olha a mulher do pão" (CEFURIA, 2016, p. 14).

Jacinta faz parte da padaria Auxiliadora do Sítio Cercado (Curitiba) e na sua fala evidencia-se o verbo aprender, que nessa ação passou a ampliar suas percepções, sua rede de convivência, sua renda. As experiências coletivas populares integraram trajetórias, fortalecendo posturas de enfrentamento diante das dificuldades cotidianas, e esse processo ganhou visibilidade por meio da forma como estruturaram o organograma das padarias comunitárias. A Figura 1 apresenta um organograma representando como essas padarias estão organizadas. Nos três círculos móveis e integradores estão as padarias, os conselhos gestores e os vetores de integração em forma de margarida que se revigoram por meio das lutas, cooperação, cursos e formação. O universo dessas padarias comunitárias é composto por trabalhadores/trabalhadoras, consumidores, fornecedores, entidades, poder público e apoiadores.

Figura 1 - Organograma da Rede de Padarias Comunitárias

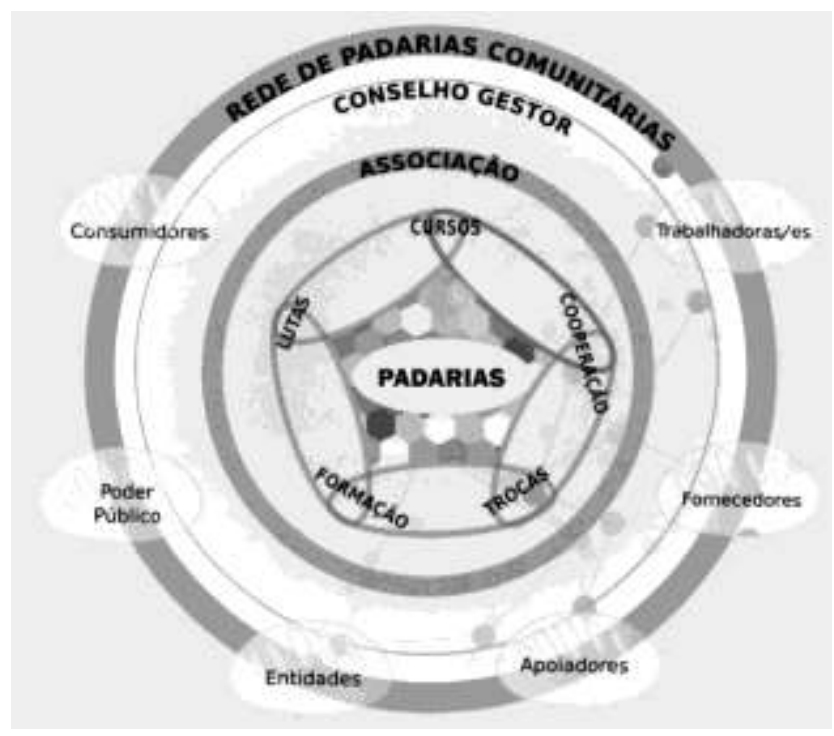

Fonte: CEFURIA (2016, p. 9).

O associativismo, por meio de (re)arranjos produtivos solidários, constrói e é construído pela tecnologia social, onde novas formas de organização possibilitam 
romper com gestões de produção exploratórias e hierarquizadas para estabelecer inserções sociais fortalecedoras da cooperação.

Nas padarias são fabricados e vendidos pães, doces, biscoitos e bolos. As receitas são muitas, mas, quando foi para decidir qual expressava a capacidade dos grupos manterem-se trabalhando unidos, criaram a seguinte receita:

começa com $50 \mathrm{Kg}$ de responsabilidade, mistura $40 \mathrm{Kg}$ de conhecimento e, aos poucos, vai adicionando a compreensão até que a união esteja homogênea. Continue batendo e acrescentando perseverança. Colocando o companheirismo para firmar a massa. Na sequência colocar $100 \%$ de sua confiança misturada com 99,9\% de diálogo, para que a massa fique leve. Por último não se esqueça de acrescentar o amor e juntar com a amizade, colocando uma pitada de perdão quando necessário e a paz para o bolo crescer (CEFURIA, 2016, p. 22).

Num primeiro momento parece uma receita que soma bons sentimentos, mas é muito mais, pois expressa as dificuldades que cercam a convivência diária. Manter as relações exige empenho, um aprender diário. Nessas interações ficou evidenciado o quanto é importante cultivar posturas construtivas, que o diálogo integra, mas o silêncio também. Errar faz parte, daí uma pitada de perdão. Nessa perspectiva, a arte de fazer pães tem o tempo da mão na massa, o do fermento na massa e o fermento fomentando compreensões, questionamentos, reflexões e experiências.

Esse livro não possui um dono, não é uma propriedade individual, não é possível alguém reivindicar como seu. Suas marcas são plurais por reunirem biografias, por também ser uma obra coletiva construída a partir de iniciativas que unem esforços e compartilham resultados. Embora reúna tantos detalhes das pessoas que lhe deram forma, conteúdos e objetivos, é também importante observar a sensibilidade do olhar para estar atento àquilo que Grinspun (2008, p. 265) afirma que "envolve questões visíveis e invisíveis, ideias e conteúdos que superam o que vemos e tocamos". Deste modo, merecem atenção as condições de trabalho, o reconhecimento social e o ganho para sobrevivência.

Além dos vários sentidos que o livro foi adquirindo entre as padeiras, como o de memória, de identidade, de definição dos valores a serem cultivados e do desenho operacional gerado pelo intercâmbio colaborativo, esse material agregou o objetivo de divulgação. O Multiplicando Sementes, com recursos da Secretaria de 
Economia Solidária gerou uma tiragem de três mil exemplares e ganhou novas inserções por meio do sítio eletrônico ${ }^{1}$. Nesse sentido, novas mãos folheiam o livro, que agora virou um material impresso com links que se conectam a outros textos, compondo um hiperdocumento importante para a comunidade. $\mathrm{O}$ resultado desse trabalho conjunto também foi publicado com a intenção de ser um instrumento de formação em educação popular e de dar visibilidade e reconhecimento às ações realizadas como parte do "Programa Curitiba Mais Humana" e resultado da parceria do CEFURIA com a FAS (Fundação de Ação Social).

As padeiras estão nas reuniões, a cozinha do fazer o pão também é sala de visitas, o Facebook é mais uma oportunidade para conhecê-las, mas não para aí. Agora estão na rua não só vendendo pães, mas também atuando como educadoras sociais junto à população em situação de rua, como mostra José, que:

se aproximou da Padaria Comunitária "O pão nosso" após ter participado de oficinas técnicas de panificação e confeitaria básica, ofertadas no Coopera Rua. As atividades foram realizadas no mesmo local onde hoje o rapaz trabalha. Ele diz estar contente de atuar no local. "Aqui todo mundo se ajuda. Não tem um patrão mandando, e a gente se diverte e faz tudo com muito amor pra comunidade" (SCHRAMM, 2017).

A análise de todas essas ações investigadas nos permite ter uma visão da cultura escolar da Escolinha do CEFURIA, que redesenha as fronteiras hierárquicas entre o erudito e o popular e fortalece a criação-produção e consumo de forma coletiva. Nesse processo é possível compreender as razões e o vigor da educação da pedagogia dos sonhos possíveis.

A segunda produção gráfica da Rede de Padarias e Cozinhas Comunitárias Fermento na Massa já nasceu com identidade - chamava-se "Ciranda das Mulheres" - e ganhou forma de fanzine, sendo depois publicado com uma tiragem de 100 exemplares com recursos da Secretaria Nacional de Economia Solidária. Fanzine, um formato de revista impressa composto socialmente, que se estivesse na web seria um bom exemplo de folksonomia, é um suporte que funciona como um laboratório onde experimentações de materiais textuais e gráficos geram

\footnotetext{
1 Disponível em: <http:/hww.facebook.com/Rede-Paranaensede-Padarias-Comunitárias-Fermento-na-Massa742292625899216>.
} 
experiências visuais inéditas. $\mathrm{Na}$ tarefa de produção do fanzine foram exigidos pesquisa e muito trabalho, sendo imprescindíveis cola, tesoura, recortes e tinta. O lema "faça você mesma" ganha pluralidade, se ressignifica e se transforma em "façamos nós mesmas" para que cada uma em coro possa gritar a mensagem "não se cale".

No companheirismo das padarias, as mudanças são percebidas na ação comunicativa, a revista foi escrita e as mensagens foram socializadas, as padeiras vendem seus pães e compartilham suas percepções de mundo. Portanto, é importante completar que as padeiras possuem a arte de fazer pães, livros e revistas: são mulheres educadoras populares.

\section{Considerações finais}

O campo investigativo do presente estudo revelou condições de vulnerabilidade socioambiental. Pessoas fragilizadas emocionalmente pelo lugar onde moram em uma configuração urbana adversa, pois habitavam cenários em colapso pela carência de infraestrutura e reduzida oportunidade de emprego. São atores que com seus modos de vida fazem as coisas acontecerem, resistem e redefinem seus espaços. As inúmeras adversidades podiam até tirar-lhes o fôlego, ampliar zonas de perigo e conflito, aumentando significativamente os desafios e também a necessidade de respostas atualizadas. Então, o que se percebe são as interações voltadas para produzir uma dada organização em meio a desordens, contradições e desalento. Todas essas reações foram vistas pela Associação de Moradores Santo Inácio de Loyola e o CEFURIA como possibilidades para conversar, compreender e interagir.

A formação das comunidades educativas, como no bairro do Boqueirão e na formação e gestão das padarias comunitárias, nos apresenta de forma concreta o quanto a liberdade impregnada de sentimentos morais impulsiona os (re)arranjos solidários a promover a interação entre as pessoas, que modificam o meio para atender melhor suas necessidades. $\mathrm{Na}$ medida em que os coletivos sociais em seus microlugares de convivência estabelecerem integrações geradas no diálogo franco e 
igualitário, a educação popular vai se fazendo presente enquanto um percurso gerador de agendas voltadas à formação e fortalecimento de filiações sociais. Movimentos que afirmam o caráter plural da democracia e redefinem pela autogestão relações de trabalho e de ganho, bem como pressionam para que os direitos constitucionais se tornem políticas públicas fortalecedoras da equidade social. Essa rede, tecida pelos próprios moradores, busca abrigar a dignidade, preservar a autoestima e assumir a responsabilidade de abraçar o território para nele operar, de forma duradoura, decisões capazes de assegurar a proteção dos ambientes em sua complexidade.

\section{Referências}

BONETI, L. W. Etnocentrismo, cultura e políticas educacionais. Caderno de Pesquisa: Pensamento Educacional, Curitiba, v. 4, n. 7, p. 161-180, jan./jun. 2009. Disponível em: $<$ http://universidadetuiuti.utp.br/Cadernos_de_Pesquisa/pdfs/cad_pesq7/10_etnocentris mo_cultura_cp7.pdf> Acesso em: 04 de fev. 2019.

CERTEAU, M. de. A invenção do cotidiano. Petrópolis: Vozes, 1994. v. 1. Artes de fazer.

CENTRO DE FORMAÇÃO URBANO RURAL IRMÃ ARAÚJO (CEFURIA). Multiplicando as sementes: Rede Paranaense de Padarias Comunitárias Fermento na Massa. Curitiba: CEFURIA e Secretaria Nacional de Economia Solidária (Senaes) do Ministério do Trabalho, 2016.

COMISSÃO ESTADUAL DA VERDADE “TERESA URBAN”. Relatório da Comissão da Verdade "Teresa Urban". Curitiba: CEV/PR, 2014. Disponível em: < http://www.forumverdade.ufpr.br/RelatorioFinal-CEV-PR-08-12-2014.pdf>. Acesso em: 17 out. 2018.

DARDOT, P.; LAVAL, C. Comum: Ensaio sobre a revolução no século XX. São Paulo: Boitempo, 2017.

FREIRE, P.; FREIRE, A. M. (Org.). Pedagogia dos sonhos possiveis. São Paulo: Paz e Terra, 2014.

GADOTI, M. Pensamento pedagógico brasileiro. São Paulo: Ática, 1991.

GRINSPUN, M. P. S. Z. Velhos cadernos, novas emoções. In: MIGNOT, A. C. V. (Org.). Cadernos à vista: escola, memória e cultura escrita. Rio de Janeiro: EdUERJ, 2008. p. 257-265.

JULIA, D. A cultura escolar como objeto histórico. Revista Brasileira de História da Educação, Campinas, n. 1, p. 9-43, jan./jun. 2001.

MAUSS, M. Sociologia e antropologia. São Paulo: Ubu Editora, 2017. 
MEJÍA J., M. R. La educación popular: una construcción colectiva desde el sur y desde abajo. In: STRECK, D. R.; ESTEBAN, M. T. (Org.). Educação popular: lugar de construção social coletiva. Petrópolis: Vozes, 2013.

MOUFFE, C. Identidade democrática e política pluralista. In: MENDES, C. (Coord.). SOARES, L. E. (Ed.). Pluralismo cultural, identidade e globalização. Rio de Janeiro: Record, 2001.

POLANYI, K. A grande transformação: as origens da nossa época. Rio de Janeiro: Campus, 2000.

PORTO-GONÇALVES, C. W. De saberes e de territórios: diversidade e emancipação a partir da experiência Latino-Americana. GEOgraphia, Rio de Janeiro, v. 8, n. 16, 2006 . Disponível em: <http://www.geographia.uff.br/index.php/geographia/article/view/203>. Acesso em: 17 out. 2018.

SCHRAMM, F. P. Em Curitiba, pessoas em situação de rua geram renda através da economia solidária. Experiências foram trazidas em Seminário, realizado em Curitiba no último dia 30. Brasil de Fato, Curitiba, 02 jun. 2017. Disponível em: $<$ https://www.brasildefato.com.br/2017/06/02/em-curitiba-pessoas-em-situacao-de-ruageram-renda-atraves-da-economia-solidaria/>. Acesso em: 17 out. 2018.

SCHUlTHEIS, F.; FRISINGHELLI, C. (Ed.). Pierre Bourdieu. En Argelia. Imágenes del desarraigo. Madrid: Consorcio Del Círculo de Bellas Artes, 2011.

SEN, A. Desenvolvimento como liberdade. São Paulo: Companhia das letras, 2010.

SMITH, A. A teoria dos sentimentos morais. São Paulo: Martins Fontes, 1999.

SOUZA, A. I. Irmã Araújo: vida e obra. 2. ed. Curitiba: Gráfica Popular - CEFURIA, 2007.

RECEBIDO: $14 / 03 / 2019$

APROVADO: 04/02/2020

RECEIVED: 03/14/2019

APPROVED: 02/04/2020

RECIBIDO: $14 / 03 / 2019$

APROBADO: 04/02/2020 